\title{
Cattle Weights on USDA Forest Service Lands by State With Cow and Calf Forage Consumption
}

\author{
By Daniel W. Uresk
}

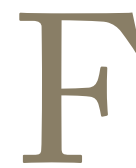

orage consumption of cows and calves is used to establish stocking rates for grazing public lands. An animal unit month (AUM) is based on a 1,000 -pound cow with calf consuming 26 pounds of oven-dry weight per day. ${ }^{1}$ Forage consumption has increased in recent years due to larger cattle and calves. ${ }^{2}$ This has prompted the USDA Forest Service to evaluate various options for change. In addition, recent public awareness has also raised concern that the animal unit and AUM needs updating. ${ }^{3}$ Here I examine current cattle weights on USDA Forest Service-managed rangelands from 30 states and, using a simple model, evaluate forage consumption of cows and calves with a range of animal weights.

\section{Methods}

Table 1 summarizes live cattle weights at slaughter from 2005 to $2008^{4,5}$ for 30 states where the USDA Forest Service manages public lands ${ }^{6}$ and compares them to summaries for 1980.7 Live weights for commercial cattle slaughter include steers, heifers, dairy cows (less than 8\%), and bulls. I developed simple dry-matter (DM) consumption models for cows and calves based on data obtained from the National Research Council ${ }^{8}$ including Digestive Physiology and Nutrition of Ruminants. ${ }^{9}$ These DM consumption models were developed independently for cows and calves.

The cows-plus-calf model is based on a calf consuming an average of 9.7 pounds of forage per day over a 6-month grazing period. Calf weight was estimated from published literature ${ }^{9-11}$ and used as a constant in the model. A calf may begin to consume forage at 6 weeks of age. I estimated that 200-pound calves turned on rangelands at the beginning of the grazing season weigh approximately 475 pounds at the end of 6 months. ${ }^{10}$ Based on this information, I determined the midpoint of calf growth to be a 338-pound calf (9.7 pounds forage consumption/day). This was used as a constant in the model for calf weight in a 6-month grazing period.

\section{Results and Discussion}

Cattle weights were highly variable over the 30 states where the USDA Forest Service manages cattle on public lands (Table 1). Average weights of cattle ranged from a low of 823 pounds in Louisiana to a high of 1,377 pounds in Arizona. Three states-Florida, Illinois, and South Dakotadid not report weights from 2005 to 2008. Cattle weights were similarly variable in 1980 , but generally lower than values reported for 2005-2008. Average cattle weight for the period 2005-2008 was 1,168 pounds compared to 1,044 pounds in 1980, a difference of 124 pounds. Overall, average cattle weights in the United States during this same period were 1,272 pounds, an increase of 200 pounds since 1980 . Live weights of mature cows in the United States were reported to be 1,396 pounds in $2005^{2}$ whereas others reported mature cow weights ${ }^{12}$ that ranged from 955 to 1,470 pounds, similar to values reported in Table 1.

I developed a simple DM consumption model for cows ranging in weight from 800 pounds to 1,400 pounds (Fig. 1). This model may be used for any class of cows and is based on cows nursing a calf with average milking ability. 8,13 The model can be applied as follows:

$$
\begin{aligned}
\text { DM consumption } & =6.34+0.014 \times \text { cow weight } \\
D M & =6.34+0.014 \times 1,168 \text { pounds } \\
D M & =6.34+16.35 \text { pounds } \\
D M & =22.7 \text { pounds } / \text { day }
\end{aligned}
$$

Figure 2 shows the relationship between calf weights ranging from 200 pounds to 700 pounds and DM consumption. This model is based on data for medium-frame steer calves gaining approximately 1.5 pounds per day. ${ }^{13}$ Heifer 
Table 1. State summaries of average live cattle weights (pounds/animal) for commercial slaughter over a 4-year period (2005-2008) and in 1980. Excluded are slaughtered farm cattle

\begin{tabular}{|c|c|c|}
\hline States & 2005-2008 & 1980 \\
\hline Arizona & 1,377 & 1,026 \\
\hline Arkansas & 988 & 889 \\
\hline California & 1,319 & 1,087 \\
\hline Colorado & 1,294 & 1,060 \\
\hline Florida & NA & 996 \\
\hline Georgia & 895 & 899 \\
\hline Idaho & 1,255 & 1,098 \\
\hline Illinois & NA & 1,058 \\
\hline Kansas & 1,259 & 1,084 \\
\hline Louisiana & 823 & 868 \\
\hline Michigan & 1,362 & 1,173 \\
\hline Minnesota & 1,391 & 1,105 \\
\hline Mississippi & 827 & 899 \\
\hline Missouri & 1,233 & 1,059 \\
\hline Montana & 1,178 & 1,105 \\
\hline Nebraska & 1,311 & 1,103 \\
\hline Nevada & 1,114 & 1,040 \\
\hline New Mexico & 1,001 & 998 \\
\hline New York & 1,161 & 1,139 \\
\hline North Dakota & 1,195 & 1,051 \\
\hline Ohio & 1,173 & 1,072 \\
\hline Oklahoma & 1,101 & 1,002 \\
\hline Oregon & 1,215 & 1,111 \\
\hline South Dakota & NA & 1,080 \\
\hline Texas & 1,215 & 1,022 \\
\hline Utah & 1,266 & 1,093 \\
\hline Virginia & 1,033 & 1,019 \\
\hline Washington & 1,299 & 1,127 \\
\hline West Virginia & 1,044 & 976 \\
\hline Wyoming & 1,193 & 1,071 \\
\hline Grand average & 1,168 & 1,044 \\
\hline US average & 1,272 & 1,072 \\
\hline \multicolumn{3}{|c|}{$\begin{array}{l}\text { States listed are those where cattle are managed on public } \\
\text { lands by the USDA-Forest Service. } \\
\text { The following states include less than the 4-year average for } \\
\text { 2005-2008: Arizona, Georgia, and Mississippi. } \\
\text { NA indicates data are not available. }\end{array}$} \\
\hline
\end{tabular}

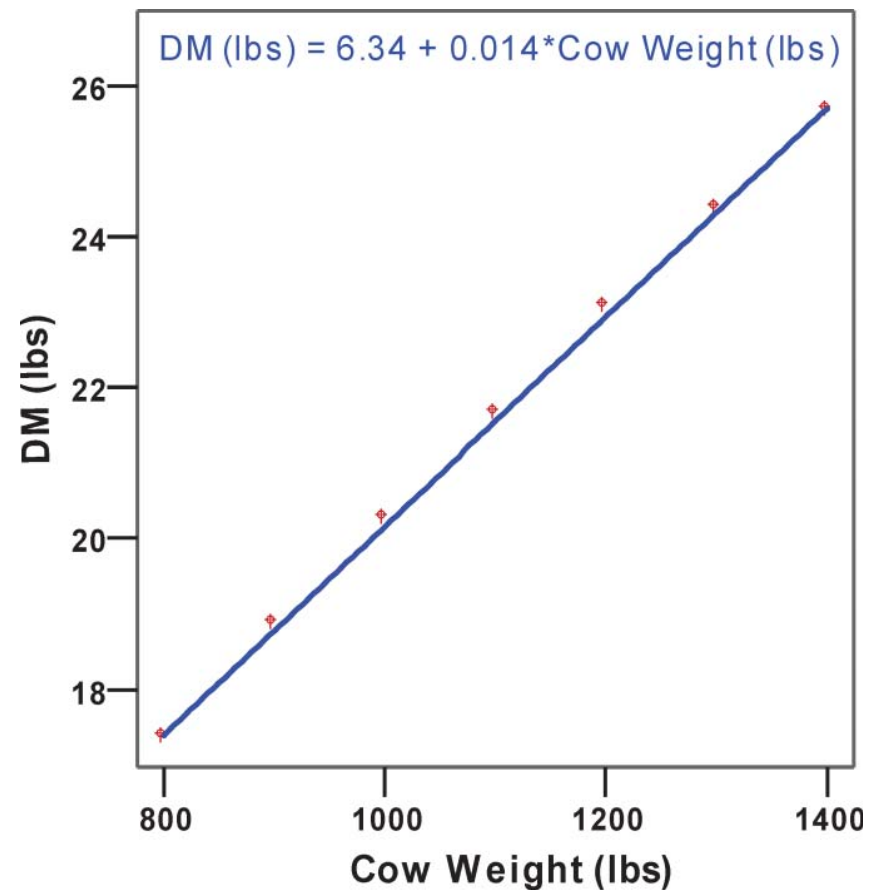

Figure 1. Relationship between cow weights, average milking, and dry matter (DM) intake with prediction equation., ${ }^{8,13}$

calves consume slightly more forage. ${ }^{9}$ The model can be applied to any class of calves as follows:

$\mathrm{DM}$ consumption $=2.95+0.02 \times$ calf weight

$$
\begin{aligned}
& \mathrm{DM}=2.95+0.02 \times 338 \text { pounds } \\
& \mathrm{DM}=2.95+6.76 \text { pounds } \\
& \mathrm{DM}=9.7 \text { pounds/day }
\end{aligned}
$$

Figure 3 presents the model developed for cow plus calf for cows ranging in weight from 800 pounds to 1,400 pounds. Again, calf weight was held constant at 338 pounds, consuming 9.7 pounds per day. An example of the model using a 1,000-pound cow plus calf (an AUM) follows:

$$
\begin{aligned}
\mathrm{DM} & \text { consumption cow }+ \text { calf } \\
& =16.04+0.014 \times \text { cow weight } \\
\mathrm{DM} & =16.04+0.014 \times 1,000 \text { pounds } \\
\mathrm{DM} & =16.04+14.00 \text { pounds } \\
\mathrm{DM} & =30.0 \text { pounds } / \text { day }
\end{aligned}
$$

A 1,000-pound cow consumes 20.3 pounds of dry matter; adding 9.7 pounds for the calf equals 30 pounds per day over the 6-month grazing period for the cow-calf pair. Using the overall cow average for cow weight in states with USDA Forest Service rangelands, a 1,168-pound cow plus calf consumes 32.4 pounds per day. When considering the US average cow weight of 1,272 pounds with calf, forage consumption is calculated at 33.8 pounds per day. However, consumption of DM forage can vary over the grazing season depending upon environmental conditions and diet. ${ }^{8,13}$

Forage consumption per unit of metabolic body weight $\left(\mathrm{W}^{0.75}\right)$ is adequate for most estimates of ruminants. ${ }^{8,14}$ 


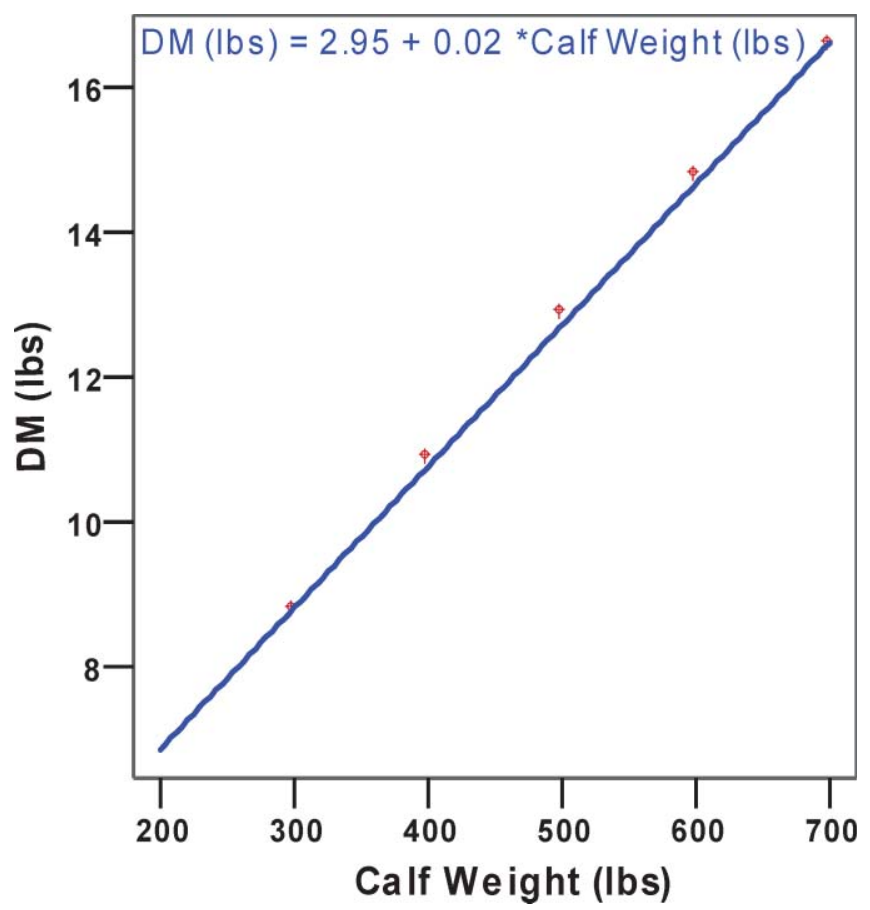

Figure 2. Relationship between calf weights and dry matter (DM) intake with prediction equation. $8,9,11,13$

Linear regression estimates taken from short segments, 800 -pound to 1,400-pound cows and calf weights from 200 pounds to 700 pounds, adequately estimate forage consumption.

\section{Implications}

1. Cattle weights were highly variable by states where the USDA Forest Service manages public lands. Weights of cattle ranged from a low of 823 pounds to a high of 1,377 pounds, when averaged over the 4-year period of 20052008. Average cattle weight for these states was 1,168 pounds whereas the average for the entire United States was 1,272 pounds.

2. The simple DM consumption models I developed can be used to estimate consumption for cow, calf, and cow plus calf weights for all classes of animals.

3. DM consumption for the current AUM cow weight, the average cow weight in 30 states with USDA Forest Service rangelands, and the overall US cow weight can be compared as follows:

$$
\begin{aligned}
& 1,000 \text {-pound cow }=20.3 \text { pounds } 1,000 \text {-pound cow } \\
& \quad+338 \text {-pound calf }=30.0 \text { pounds } / \text { day } \\
& 1,168 \text {-pound cow }=22.7 \text { pounds } ; 1,168 \text {-pound cow } \\
& \quad+338 \text {-pound calf }=32.4 \text { pounds } / \text { day } \\
& 1,272 \text {-pound cow }=24.1 \text { pounds } 1,272 \text {-pound cow } \\
& \quad+338 \text {-pound calf }=33.8 \text { pounds } / \text { day }
\end{aligned}
$$

This indicates that as cows are increasing in weight, allowance must be made for greater forage consumption, and a revision to the AUM may be needed.

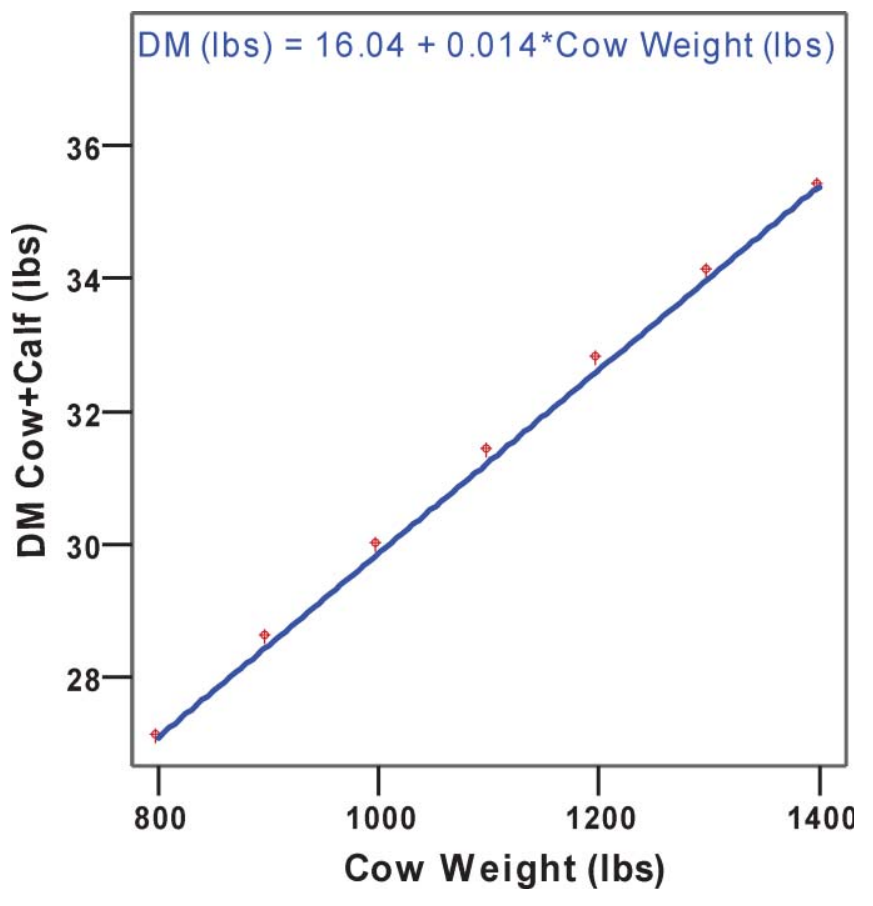

Figure 3. Relationship between cow weights plus 338-pound calf with dry matter (DM) intake. Calf weight of 338 pounds was considered an average weight over a 6-month grazing period., ${ }^{8,13}$

4. Application of these simple models for DM consumption of cows and calves can be determined by state and by region. This will require monitoring of cattle stocking rates and adjustments based on rangeland herbage production, grazing use, and plant trends.

\section{Acknowledgments}

Special thanks are extended to Marty Vavra, Tom Juntti, and David Beard for offering helpful comments on earlier drafts of this manuscript. I gratefully acknowledge Lori Hidinger for final editing of the manuscript.

\section{References}

1. Ruyle, G., and P. Ogden. 1993. What is an A.U.M.? In: R. Tronstat and G. Ruyle [EDs.]. Arizona Ranchers' Management Guide. Tucson, AZ, USA: Arizona Cooperative Extension. p. 1-4.

2. McMurry, B. 2009. Cow size is growing. Available at: http:// beefmagazine.com/genetics/0201-increased-beef-cows/. Accessed 29 June 2010.

3. Carter, J. G. 2008. Updating the animal unit month. Mendon, UT, USA: Western Watershed Project, Inc. 7 p.

4. USDA-National Agricultural Statistics Service. 2007. Livestock slaughter 2006 summary. Mt An 1-2-1 (07). Summary for live cattle weights by states 2005-2006. Available at: http:// usda.mannlib.cornell.edu/MannUsda/viewDocumentInfo. do?documentID=1097. Accessed 12 August 2009.

5. USDA-National Agricultural Statistics Service. 2009. Livestock slaughter 2008 summary. Mt An 1-2-1 (09). Summary 
for live cattle weights by states 2007-2008. Available at: http:// usda.mannlib.cornell.edu/MannUsda/viewDocumentInfo. do?documentID=1097. Accessed 12 August 2009.

6. USDA Forest Service-Range Management. 2009. Grazing statistical summary FY 2008. Available at: http://www.fs.fed. us/rangelands/reports/index.shtml. Accessed 12 August 2009.

7. USDA-Crop Reporting Board, Economics and StatisTics Service. 1981. Livestock slaughter, annual summary 1980. Available at: http://usda.mannlib.cornell.edu/MannUsda/ viewDocumentInfo.do?documentID=1097. Accessed 12 August 2009.

8. National Research Council. 1984. Nutrient requirements of beef cattle. 6th ed. Washington, D.C., USA: National Academy of Sciences Press. 90 p.

9. Church, D. C. 1972. Digestive physiology and nutrition of ruminants. Volume 3. Practical nutrition. Corvallis, OR, USA: Oregon State University Press. 351 p.

10. Funston, R. 2007. Lowering beef cattle production costs.
Available at: http//www.mtbeefnetwork.org/article/general/ prod_costs.html. Accessed 12 August 2009.

11. Church, D. C. 1975. Digestive physiology and nutrition of ruminants. Volume 1. Digestive physiology. Corvallis, OR, USA: Oregon State University Press. 350 p.

12. Dhuyvetter, J. 1995. Beef cattle frame scores. Available at: http://showsteers.com/NAV/Frame\%20Score\%Chart.htm. Accessed 24 February 2010.

13. Oregon State University. 2004. Beef cattle nutrition workbook. Corvallis, OR, USA: Oregon State Extension Service. $69 \mathrm{p}$.

14. Cordova, F. J., J. D. Wallace, and R. D. Pieper. 1978. Forage intake by grazing livestock: a review. Journal of Range Management 31:430-438.

Author is Senior Research Biologist, USDA Forest Service, Rapid City, SD 57701, USA, duresk@fs.fed.us. 